\title{
Der Keimapparat von h. Th. Entel.
}

Seber Forfmann weiß, wie wiđtig bie Erprobung ber Reintraft jenter $\mathfrak{B a r b}_{\text {a }}$

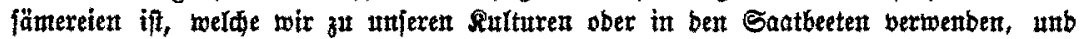
swie burch bie Duatität bes Samens bie Menge bes zu verwenbenben Samens wie bas

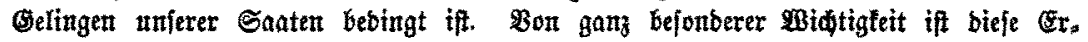

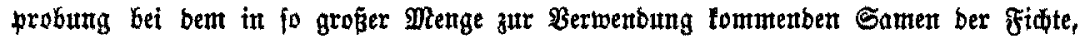

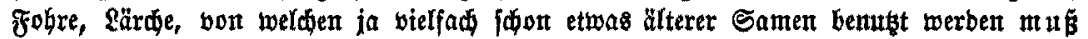

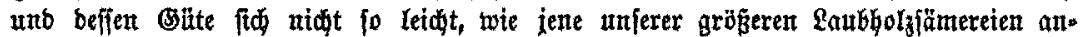

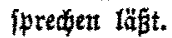

Bon jeher Gat man biejer Unterfudung ber Reimtraft getannter Sämereien baher

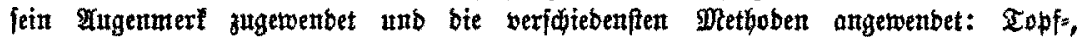

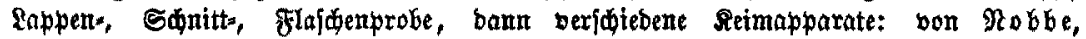

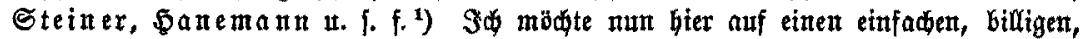

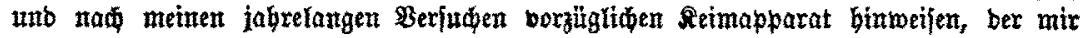
nidgt gentilgenb befant unb ver6reitet zu fein foeint: auf ben Reimapporat von

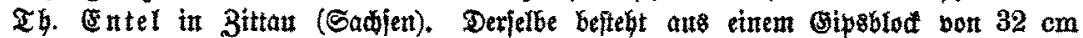

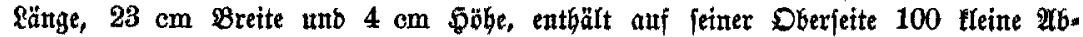

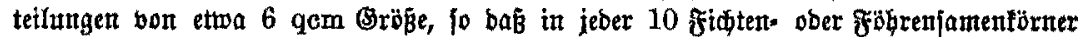

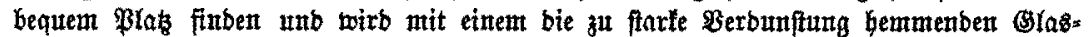

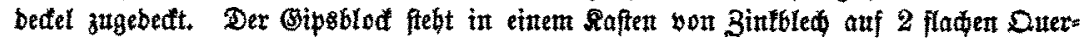

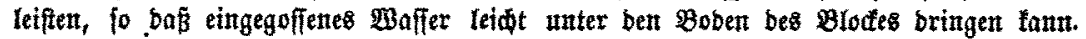

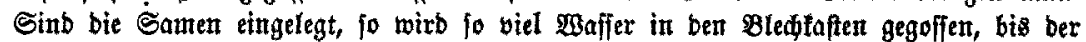

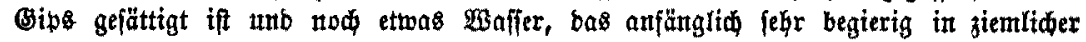

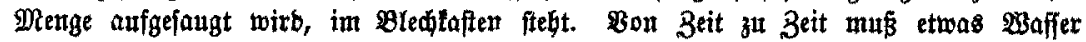
tacdgeffitut twerben.

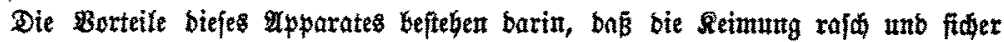

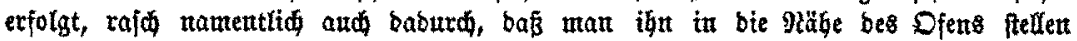

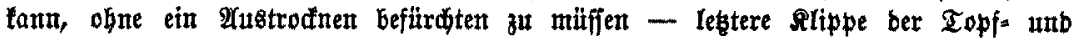
Lapperprobe wirb bolffätübig bermiesen; ferner barin, baß̄ man eine ganze Menge bout Reimproben - bis zu 10 à 100 Rörner - gletdjzeitig bornebmen tann, wa ja eben

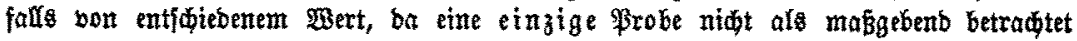

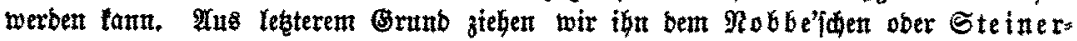
fiden Reimtapparat entijđieben bor.

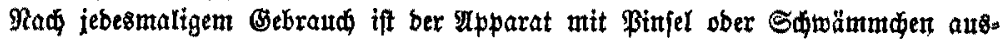

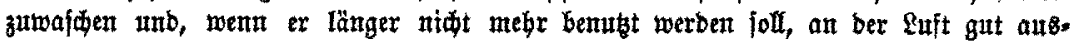
zutrođnen.

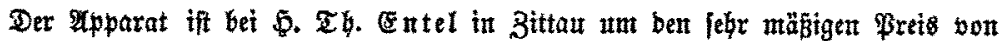
3,50 . genofien befters empfoblen.

Für $\mathrm{rtt.}$

\section{Winterḩerberge der fledermăuje.}

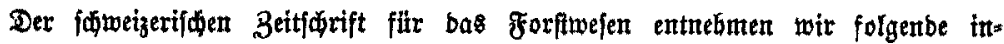

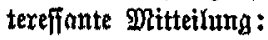

Im 26. Dezember 1896 wurbe burd bor

1) Bergl. Fitrf, Bflamzenzudt, 3. צuff. 1897.

Forftwifieuridaftlides 厄entralbratt. 1897. 